\title{
Use of the microalga Scenedesmus obliquus to remove cadmium cations from aqueous solutions
}

\author{
Cristina M. Monteiro - Paula M. L. Castro • \\ F. Xavier Malcata \\ C. M. Monteiro - P. M. L. Castro · F. X. Malcata $(\square)$ \\ $\mathrm{CBQF} /$ Escola Superior de Biotecnologia, Universidade Católica \\ Portuguesa, Rua Dr. António Bernardino de Almeida, \\ 4200-072 Porto, Portugal \\ e-mail: fxmalcata@esb.ucp.pt
}

Keywords Microalga - Heavy metal - Bioaccumulation · Biosorption $\cdot \mathrm{pH} \cdot$ Inactivated biomass

\begin{abstract}
The ability of a wild strain of Scenedesmus obliquus, isolated from a heavy metal-contaminated environment, to remove $\mathrm{Cd}^{2+}$ from aqueous solutions was studied at several initial concentrations. Viable biomass removed metal to a maximum extent of $11.4 \mathrm{mg}_{\mathrm{Cd}} / \mathrm{g}$ at $1 \mathrm{mg}_{\mathrm{Cd}} / \mathrm{l}$, with most $\mathrm{Cd}^{2+}$ being adsorbed onto the cell surface. A commercially available strain (ACOI 598) of the same microalga species was also exposed to the same $\mathrm{Cd}$ concentrations, and similar results were obtained for the maximum extent of metal removal. Heat-inactivated cells removed a maximum of $6.04 \mathrm{mg}_{\mathrm{Cd}} / \mathrm{g}$ at $0.5 \mathrm{mg}_{\mathrm{Cd}} / \mathrm{l}$. The highest extent of metal removal, analyzed at various $\mathrm{pH}$ values, was $0.09 \mathrm{mg}_{\mathrm{Cd}} / \mathrm{g}$ at $\mathrm{pH} 7.0$. Both strains of the microalga tested have proven effective in removing a toxic heavy metal from aqueous solutions, hence supporting their choice for bioremediation strategies of industrial effluents.
\end{abstract}

\section{Introduction}

Contamination of water bodies by heavy metals leached from industrial effluents is currently a serious environmental problem (Bayramoğlu and Arica 2008; Fraile et al. 2005). This form of pollution has the particular disadvantage of not being susceptible to biodegradation, hence leading to bioaccumulation throughout the food chain (Doshi et al. 2007a).
Cadmium is one good example of such metal pollution. It is often present in paint pigments, alloys, metal platings and batteries (Pérez-Rama et al. 2002; Solisio et al. 2008). Being a non-essential metal to living organisms, it can displace essential metals (e.g. Zn) with specific biological functions, so chronic exposure to high levels of $\mathrm{Cd}$ may result in kidney or liver damage, bone degeneration, and even cancer (Doshi et al. 2007a; Solisio et al. 2008).

Several authors have been searching for alternative and better performing remediation strategies pertaining to toxic heavy metals, because conventional physico-chemical methods (e.g. precipitation and ion-exchange) are not fully effective; in addition, they are rather expensive (Bayramoğlu and Arica 2008; Doshi et al. 2007b), especially when the metal levels are of the ppm order of magnitude (Gupta and Rastogi 2008a; Yu and Kaewsarn 1999).

A more feasible approach relies on the metal binding and uptake capacities of living materials, which include microalgae in particular (Doshi et al. 2007b; Fraile et al. 2005; Leborans and Novillo 1996; Rollemberg et al. 1999; Solisio et al. 2008). Application of microbial biomass to remove toxic heavy metals has become relatively popular, owing to its high adsorbing capacity and low cost (Bayramoğlu and Arica 2008; Doshi et al. 2007b). Additionally, metals removed by adsorption onto the cell surface, may be successfully recovered, after desorption brought about by chemical agents: Costa and França (1998) reported that a $10.0 \mathrm{~g} / 1$ EDTA solution could totally recover the $\mathrm{Cd}$ previously removed by adsorption onto the cell walls of the microalga Tetraselmis chuii, whereas Gupta and Rastogi (2008b) obtained 85 and $80 \%$ recoveries of $\mathrm{Cd}$ ions from 
Oedogonium sp. biomass, when using $\mathrm{HCl}$ or EDTA as desorbing agents, respectively.

The level of metal removal by a microalga depends on several processing factors, such as supernatant metal and biomass concentrations, as well as $\mathrm{pH}$ and contact time (Aksu and Dönmez 2006; Solisio et al. 2008; Tang et al. 2002). Such a phenomenon occurs via a dual mechanism, which encompasses biosorption and bioaccumulation. The former is a passive event, which is independent of cell metabolism, and is based on physicochemical interactions between metal and functional groups on the cell wall. Conversely, bioaccumulation depends on cell metabolism, and takes place when metal ions are incorporated intracellularly (Özer et al. 1999; Rangsayatorn et al. 2002).

The aim of this study was to test the ability of a wild strain of Scenedesmus obliquus, isolated from a polluted site in Portugal, to remove $\mathrm{Cd}$ ions from aqueous solution-using either viable or inactivated biomass, upon exposure to several $\mathrm{Cd}$ concentrations and $\mathrm{pH}$ values. It has been claimed that microalgal species isolated from polluted environments are usually more resistant and more capable of accumulating heavy metals (Chong et al. 2000), so a reference strain of S. obliquus (ACOI 598) was also tested in this study, to ascertain whether the extent of metal removal under regular operating conditions was affected by strain source.

\section{Experimental}

Microalgal biomass and stock solution

The Scenedesmus obliquus strain (L) was isolated from a region of Northern Portugal that has been polluted with heavy metals for several decades- "Esteiro de Estarreja". The contaminated sediments include mainly the following heavy metals: $835 \mathrm{mg} \mathrm{Pb} / \mathrm{kg}, 66 \mathrm{mg} \mathrm{Hg} / \mathrm{kg}$ and 3,620 mg Zn/kg, with other metals detected at lower levels (Oliveira et al. 2001). The $S$. obliquus strain (ACOI 598) was obtained from the alga culture collection (ACOI) held by University of Coimbra (Portugal).

Both microalga strains were cultivated in PHM medium (Borowitzka and Borowitzka 1988), with $1 \mathrm{~g} / \mathrm{l}$ Tris- $\mathrm{HCl}$ buffer but without EDTA, and were maintained at $25^{\circ} \mathrm{C}$ under continuous illumination. Cultures in the exponential growth phase were used in all experimental batch cultures.

A stock solution of $\mathrm{Cd}^{2+}$ was prepared by diluting solid $\mathrm{CdCl}_{2}$ in deionized water. Defined volumes of the stock solution were added to the growth medium, in order to obtain the desired final concentrations.

All material used was previously rinsed once with nitric acid, and several times with deionised water afterwards, to prevent analytical interferences.
Cd removal by viable biomass

Both strains of S. obliquus (strains L and ACOI 598) were exposed, in triplicate, at an initial biomass concentration of $0.02 \mathrm{~g} / 1$, to $0.05,0.1,0.25,0.5$ and $1 \mathrm{mg}_{\mathrm{Cd}} / 1$ for 7 days. Aliquots of $75 \mathrm{ml}$ were collected daily, in duplicate, and were used to quantify biomass growth and Cd removal, both by adsorption on the cell wall and by absorption into the microalgal cells.

Cell growth was determined by measuring the optical density (OD) at $600 \mathrm{~nm}$, and subsequently converting it to dry weight (DW) using a calibration curve prepared in advance. Metal removal was determined following the method of Matsunaga et al. (1999) and Pérez-Rama et al. (2002), after sample centrifugation at 4,000 rpm for $15 \mathrm{~min}$ at $4{ }^{\circ} \mathrm{C}$ (to separate the biomass). Subsequently, the pellet was washed for 20 min with a 0.02 M EDTA solution (to remove $\mathrm{Cd}$ ions adsorbed onto the cell surface); this fraction was disposed of, and after another centrifugation, the pellet was digested with $1 \mathrm{ml}$ of $15 \mathrm{M} \mathrm{HNO}_{3}$ and $0.5 \mathrm{ml}$ of $70 \%$ $\mathrm{HClO}_{4}$; the $\mathrm{Cd}$ concentration in the supernatant was finally determined by atomic absorption spectrophotometry.

The total concentration of $\mathrm{Cd}$ removed by microalgal cells was calculated as the difference between the initial and the remaining $\mathrm{Cd}$ in the supernatant; the concentration of $\mathrm{Cd}$ adsorbed onto the cell surface was, in turn, determined as the difference between the total concentration of $\mathrm{Cd}$ removed and that of intracellular $\mathrm{Cd}$.

Replicated blank controls, containing culture medium plus metal at each concentration tested, were considered; the $\mathrm{Cd}$ concentration remained stable in those flasks for the time frame of each experiment, so no redox reaction or adsorption onto the vessel walls took place to any measurable extent. The initial $\mathrm{Cd}$ concentrations in the experimental flasks were also confirmed by taking an aliquot of the culture medium before adding the microalga biomass, and assaying for $\mathrm{Cd}$ as described above.

\section{Cd removal by inactive biomass}

The biomass of S. obliquus strain (L) was harvested in the exponential phase, and inactivated by heating at $100^{\circ} \mathrm{C}$ for $24 \mathrm{~h}$. Removal experiments using different initial concentrations $\left(0.05,0.1,0.25,0.5\right.$ and $\left.1 \mathrm{mg}_{\mathrm{Cd}} / 1\right)$, at an initial biomass concentration of $0.02 \mathrm{~g} / 1$, were conducted in triplicate. Following centrifugation, the supernatant was assayed for the remaining metal concentration.

\section{Cd removal as affected by $\mathrm{pH}$}

The influence of $\mathrm{pH}$ was tested by exposing $0.27 \mathrm{~g} / \mathrm{l}$ of viable biomass of $S$. obliquus strain (L), in triplicate, to an initial concentration of $0.3 \mathrm{mg}_{\mathrm{Cd}} / 1$, under $\mathrm{pH}$ values 
ranging from 3.0 to 7.0. Aliquots were taken by $120 \mathrm{~min}$ and, after centrifugation, the supernatant was analysed for total $\mathrm{Cd}$ removed. In this test, the biomass concentration used was ca. 10 times higher than that of the remaining experiments, due to the reduced contact time.

Statistical analyses

Statistical analyses of the experimental data were conducted using SPSS, v. 16.0 (Chicago IL, USA). Analysis of variance (ANOVA) was applied to the experimental results, as well as Student's $t$-test and Tukey's test, aiming at pinpointing statistically significant (at the 5\% level) differences between means.

\section{Results}

Cd removal by S. obliquus biomass

The degree of Cd removal by living cells of both strains, under various initial $\mathrm{Cd}$ concentrations, for a period of 7 days, is represented in Fig. 1. For both ecotypes, removal increased with increasing initial metal concentration, but
Fig. 1 Total amounts of $\mathrm{Cd}$ removed, adsorbed and absorbed, as a function of contact time (mean \pm standard deviation, $n=3$ ), by viable (1) Scenedesmus obliquus (L) and (2) S. obliquus (ACOI 598) biomass, at various initial $\mathrm{Cd}$ concentrations, viz. a 0.05 , b 0.1 , c 0.25 , d 0.5 and e $1 \mathrm{mg} / \mathrm{l}$. The microalga biomass concentration was $0.02 \mathrm{~g} / \mathrm{l}$; the amounts of $\mathrm{Cd}$ adsorbed on and absorbed by the $S$. obliquus (ACOI 598) cells could not be measured at $1 \mathrm{mg} / \mathrm{l}$
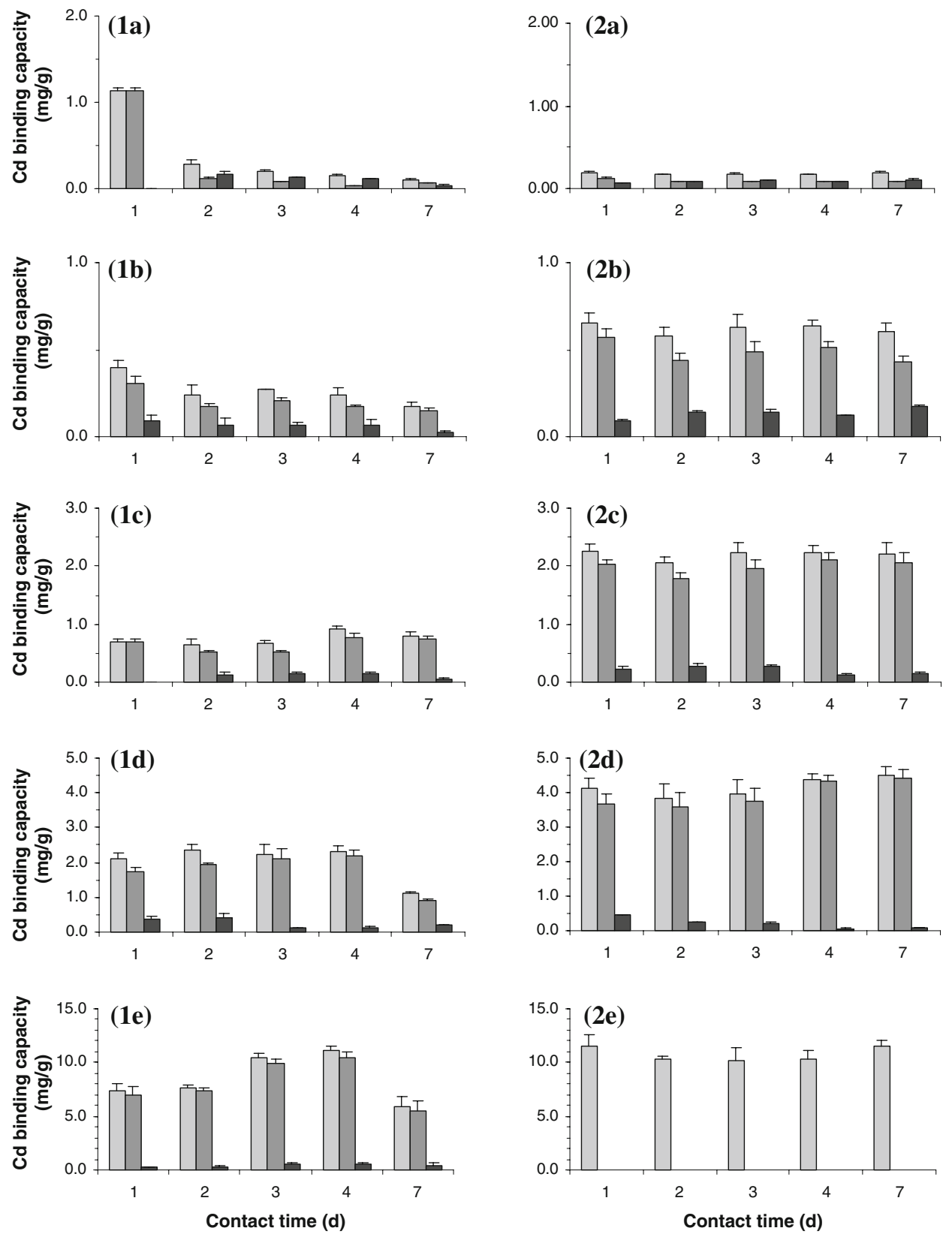

$\square$ Total Cd removed $\square$ Cd adsorbed $\square$ Cd absorbed 
almost all metal biosorption was achieved within the first day of exposure. The maximum levels of removal were 11.4 and $11.5 \mathrm{mg} / \mathrm{g}$, by $S$. obliquus strains (L) and (ACOI 598), respectively. Additionally (except for the lowest $\mathrm{Cd}$ concentration tested), the metal was removed mainly by adsorption onto the cell surface.

When inactivated biomass was employed, the $\mathrm{Cd}$ removal by $S$. obliquus strain (L), upon exposure for $90 \mathrm{~min}$ to the various initial metal concentrations, is depicted in Fig. 2; it is apparent that the total amount of $\mathrm{Cd}$ removed was higher at higher initial concentrations, with a maximum degree of removal of $6.04 \mathrm{mg}_{\mathrm{Cd}} / \mathrm{g}$ at $0.5 \mathrm{mg}_{\mathrm{Cd}} / \mathrm{l}$. The maximum extent of $\mathrm{Cd}$ removal was achieved by $15 \mathrm{~min}$, at all initial concentrations tested, and was followed by a slight decrease until an apparent equilibrium was eventually reached by $120 \mathrm{~min}$.

Cd removal as affected by $\mathrm{pH}$

The influence of solution $\mathrm{pH}$ upon the degree of $\mathrm{Cd}$ removal by the wild microalga biomass is represented in Table 1, for a period of $120 \mathrm{~min}$. At higher $\mathrm{pH}$, the total $\mathrm{Cd}$

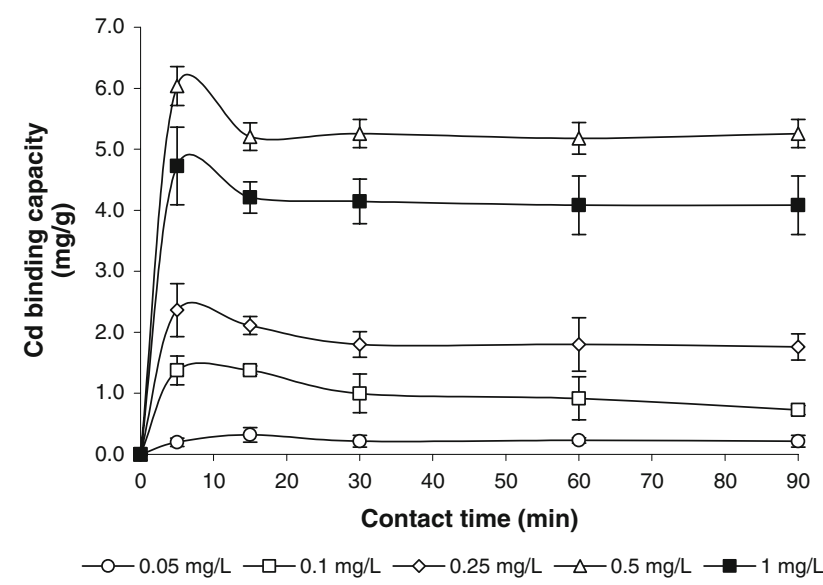

Fig. 2 Total amount of $\mathrm{Cd}$ removed, as a function of contact time (mean \pm standard deviation, $n=3$ ), by inactivated Scenedesmus obliquus (L) biomass, at various initial Cd concentrations, viz. 0.05, $0.1,0.25,0.5$ and $1 \mathrm{mg} / \mathrm{l}$. The microalga biomass concentration was $0.02 \mathrm{~g} / \mathrm{l}$

Table 1 Total amount of $\mathrm{Cd}$ removed, as a function of $\mathrm{pH}$ (mean \pm standard deviation, $n=3$ ), by viable Scenedesmus obliquus (L) biomass, by $120 \mathrm{~min}$ of exposure

\begin{tabular}{ll}
\hline $\mathrm{pH}$ & Concentration of Cd removed $(\mathrm{mg} / \mathrm{g})$ \\
\hline 3 & $0.036 \pm 0.007$ \\
4 & $0.018 \pm 0.008$ \\
5 & $0.054 \pm 0.007$ \\
6 & $0.034 \pm 0.004$ \\
7 & $0.087 \pm 0.011$
\end{tabular}

The microalga biomass concentration was $0.27 \mathrm{~g} / 1$ removed was higher; a maximum removal extent of 0.087 $\mathrm{mg}_{\mathrm{Cd}} \mathrm{g}$ was achieved at $\mathrm{pH} 7.0$, which is significantly $(P<0.05)$ higher than that observed at the other $\mathrm{pH}$ values. The lowest removal extent $\left(0.018 \mathrm{mg}_{\mathrm{Cd}} / \mathrm{g}\right)$ was observed at $\mathrm{pH} 4.0$, yet no significant $(P>0.05)$ differences were detected between this value and those obtained at either $\mathrm{pH} 3.0$ or 6.0 .

\section{Discussion}

Cd removal by S. obliquus biomass

Living microalga biomass has been used for bioremediation processes of heavy metal-contaminated wastewaters, owing to its ability to remove such contaminants, either by adsorption onto the cell surface or by incorporation into the cells themselves. Two distinct biochemical paths can thus be followed: biosorption (or adsorption of metal ions onto the cell surface) and bioaccumulation (or absorption of metal into the cell) (Rangsayatorn et al. 2002). In our study, the pattern of $\mathrm{Cd}$ removal-with maxima reached very early during exposure, followed by a slight decrease and eventually by a plateau, was consistent with that described by Torres et al. (1998). Additionally, the increase observed in total metal removal, as the metal concentrations in the supernatant solution were set higher, was also described elsewhere (Costa and França 1998; Özer et al. 1999). Except for the lowest Cd concentration (for which the amount of $\mathrm{Cd}$ uptaken by the cells overcame the amount adsorbed), the metal was removed by both ecotypes chiefly by adsorption onto the cell surface. The cell wall of microorganisms has been claimed to play a crucial role as a defence mechanism -in that it is the first barrier to the uptake of toxic metals (Özer et al. 1999; Rangsayatorn et al. 2002). Maximum extents of Cd removal attained in our case were $11.4-11.5 \mathrm{mg}_{\mathrm{Cd}} / \mathrm{g}$, upon exposure to $1 \mathrm{mg}_{\mathrm{Cd}} / \mathrm{l}$. A similar finding was reported by Costa and França (1998): T. chuii was able to remove a maximum of $8.54 \mathrm{mg}_{\mathrm{Cd}} / \mathrm{g}$, when in the presence of $1 \mathrm{mg}_{\mathrm{Cd}} / \mathrm{l}$. Dönmez et al. (1999) reported, for other metals, a pattern identical to that obtained by us; when studying the biosorption capacity of the microalga $S$. obliquus upon exposure to $\mathrm{Cu}(\mathrm{II})$, $\mathrm{Ni}$ and $\mathrm{Cr}(\mathrm{VI})$, at concentrations ranging in $25-$ $224 \mathrm{mg} / \mathrm{l}$, they observed that maximum metal removal was attained for the highest initial metal concentration, viz. $26.8 \mathrm{mg} / \mathrm{g}$ for $\mathrm{Cu}(\mathrm{II}), 24.7 \mathrm{mg} / \mathrm{g}$ for $\mathrm{Ni}$ and $30.2 \mathrm{mg} / \mathrm{g}$ for $\mathrm{Cr}(\mathrm{VI})$. Cain et al. (1980) also described that bioaccumulation of $\mathrm{Cd}$ by the same microalga increased with increasing external $\mathrm{Cd}$ concentrations, and claimed a maximum bioacumulation of $3,031 \mathrm{ppm}$ when subject to an initial concentration of $1.0 \mathrm{mg} / \mathrm{l}$. Drbal et al. (1985) and Travieso et al. (1999) concluded that S. obliquus and 
(immobilized) Scenedesmus acutus could remove a maximum of 39 and $74 \%$ of $\mathrm{Cd}$ from solution, respectively, following contact with an initial concentration of $0.5 \mathrm{mg} / \mathrm{l}$ of that metal. Furthermore, higher removal capacities were found by Terry and Stone (2002) in the case of Scenedesmus abundans, ranging from 139 to $574 \mathrm{mg} / \mathrm{g}$, when the biomass was exposed to initial $\mathrm{Cd}$ concentrations from 5 to $20 \mathrm{mg} / \mathrm{l}$.

Although it has been claimed that microalgae isolated from contaminated environments may exhibit a higher metal removal capacity than those grown in otherwise clean environments (Chong et al. 2000), this was not the case in our study. This realisation may be rationalized by the fact that $\mathrm{Cd}$ is not a major environmental pollutant of the site from which the strain was isolated, unlike other heavy metals, viz. $\mathrm{Pb}, \mathrm{Hg}$ and $\mathrm{Zn}$ (Oliveira et al. 2001).

Inactivated microalgal biomass has been successfully used in heavy metal adsorption trials, for which it possesses the advantages of not requiring nutrients to survive, and withstanding highly toxic environments (Aksu and Dönmez 2006; Solisio et al. 2008). The fast binding of $\mathrm{Cd}$ within the first minutes of contact-which is essentially followed by a plateau, hence suggests that the metal is removed via interactions with functional groups on the surface; Bayramoğlu and Arica (2008) have concluded likewise. Comparing the $\mathrm{Cd}$ removal capacity of viable and inactivated biomass, via a Student's $t$-test, it is clear that the latter removes significantly $(P<0.05)$ more $\mathrm{Cd}$ ions when exposed to $0.1,0.25$ and $0.5 \mathrm{mg}_{\mathrm{Cd}} / 1$. As reported by Bayramoğlu and Arica (2008) when studying metal removal by heat-inactivated fungi, thermal treatment may generate additional binding sites via denaturation of proteins on the cell wall structures, thus promoting metal removal.

\section{Cd removal as affected by $\mathrm{pH}$}

The extent of metal removal using biosorbents depends on the $\mathrm{pH}$ of the supernatant solution, as this parameter affects the protonation state of the functional groups on the biomass cell wall (Bayramoğlu and Arica 2008; Gupta and Rastogi 2008a). At low pH, the surface charge of the cell wall is indeed positive, so it constrains binding of (positive) metal cations. As $\mathrm{pH}$ is raised, more ligands bearing negative charges become exposed on the surface of the cell wall, with subsequent attraction of metal ions (Gupta and Rastogi 2008a; Tüzün et al. 2005). Our data indicated that the optimum $\mathrm{pH}$ for $\mathrm{Cd}$ removal is 7.0 (which was the highest $\mathrm{pH}$ tested); therefore, an increase in $\mathrm{pH}$ enhances metal removal from solution, as there is a lower competition between protons and metal cations for the active sites on the biomass cell wall. Several other researchers have shown a similar dependence of metal removal on pH: e.g. Tüzün et al. (2005) and Bayramoğlu and Arica (2008) described an increase in $\mathrm{Cd}$ removal up to $\mathrm{pH}$ 6.0, whereas Fraile et al. (2005) reported maximum $\mathrm{Cd}$ removal at $\mathrm{pH}$ 8.0.

\section{Conclusions}

The microalga $S$. obliquus is well suited to remove $\mathrm{Cd}^{2+}$ ions from aqueous solutions, and such a removal is a rapid process; the good sorption capacity of those microorganisms is comparable to that of other microalgae described in the literature. On the other hand, the commercial strain presents a $\mathrm{Cd}$ removal capacity essentially similar to that of the wild strain.

Most metal is removed from solution via adsorption onto the cell surface (except at the lowest $\mathrm{Cd}$ concentration tested, for which absorption appears to dominate). Accordingly, heat-inactivated biomass proved able to remove most $\mathrm{Cd}^{2+}$ ions from solution, thus confirming its potential applicability in wastewater treatment.

Finally, Cd removal from solution depends on $\mathrm{pH}$, with a maximum level of removal at ca. $\mathrm{pH}$ 7.0.

Acknowledgments The authors are grateful to Câmara Municipal de Estarreja (Portugal) for allowing full access to the contaminated site. This work was supported by Fundação para a Ciência e Tecnologia (FCT) and Fundo Social Europeu (FSE-III Quadro Comunitário de Apoio), via a $\mathrm{PhD}$ research fellowship granted to author Monteiro (ref. SFRH/BD/9332/2002).

\section{References}

Aksu Z, Dönmez G (2006) Binary biosorption of cadmium(II) and nickel(II) onto dried Chlorella vulgaris: co-ion effect on monocomponent isotherm parameters. Process Biochem 41:860-868. doi:10.1016/j.procbio.2005.10.025

Bayramoğlu G, Arica MY (2008) Removal of heavy mercury(II), cadmium(II) and zinc(II) metal ions by live and heat inactivated Lentinus edodes pellets. Chem Eng J 143:133-140. doi: 10.1016/j.cej.2008.01.002

Borowitzka MA, Borowitzka LJ (1988) Algal media and sources of algal cultures. In: Borowitzka MA, Borowitzka LJ (eds) Microalgal biotechnology. Cambridge University Press, Cambridge, pp 456-466

Cain JR, Paschal DC, Hayden CM (1980) Toxicity and bioaccumulation of cadmium in the colonial green alga Scenedesmus obliquus. Arch Environ Contam Toxicol 9:9-16. doi:10.1007/ BF01055495

Chong AMY, Wong YS, Tam NFY (2000) Performance of different microalgal species in removing nickel and zinc from industrial wastewater. Chemosphere 41:251-257. doi:10.1016/S0045-6535 (99)00418-X

Costa ACA, França FP (1998) The behaviour of the microalgae Tetraselmis chuii in cadmium-contaminated solutions. Aquacult Int 6:57-66. doi:10.1023/A:1009221820135

Dönmez GÇ, Aksu Z, Öztürk A, Kutsal T (1999) A comparative study on heavy metal biosorption characteristics of some algae. Process Biochem 34:885-892. doi:10.1016/S0032-9592(99)00005-9 
Doshi H, Ray A, Kothari IL (2007a) Biosorption of cadmium by live and dead Spirulina: IR spectroscopic, kinetics and SEM studies. Curr Microbiol 54:213-218. doi:10.1007/s00284-006-0340-y

Doshi H, Ray A, Kothari IL (2007b) Bioremediation potential of live and dead Spirulina: spectroscopic, kinetics and SEM studies. Biotechnol Bioeng 96:1051-1063. doi:10.1002/bit.21190

Drbal K, Véber K, Zahradník J (1985) Toxicity and accumulation of copper and cadmium in the alga Scenedesmus obliquus LH. Bull Environ Contam Toxicol 34:904-908. doi:10.1007/BF01609824

Fraile A, Penche S, González F, Blázquez ML, Muñoz JA, Ballester A (2005) Biosorption of copper, zinc, cadmium and nickel by Chlorella vulgaris. Chem Ecol 21:61-75. doi:10.1080/02757540 512331334933

Gupta VK, Rastogi A (2008a) Biosorption of lead from aqueous solutions by green algae Spirogyra species: kinetics and equilibrium studies. J Hazard Mater 152:407-414. doi:10.1016/ j.jhazmat.2007.07.028

Gupta VK, Rastogi A (2008b) Equilibrium and kinetic modelling of cadmium (II) biosorption by nonliving algal biomass Oedogonium sp. from aqueous phase. J Hazard Mater 153:759-766. doi: 10.1016/j.jhazmat.2007.09.021

Leborans GF, Novillo A (1996) Toxicity and bioaccumulation of cadmium in Olisthodiscus luteus (Raphidophyceae). Water Res 30:57-62. doi:10.1016/0043-1354(95)00084-X

Matsunaga T, Takeyama H, Nakao T, Yamazawa A (1999) Screening of marine microalgae for bioremediation of cadmium-polluted seawater. J Biotechnol 70:33-38. doi:10.1016/S0168-1656(99) 00055-3

Oliveira RS, Dodd JC, Castro PML (2001) The mycorrhizal status of Phragmites australis in several polluted soils and sediments of an industrialised region of Northern Portugal. Mycorrhiza 10:241-247. doi:10.1007/s005720000087

Özer A, Özer D, Dursun G, Bulak S (1999) Cadmium (II) adsorption on Cladophora crispata in batch stirred reactors in series. Waste Manag 19:233-240. doi:10.1016/S0956-053X(99)00082-3

Pérez-Rama M, Alonso JA, López CH, Vaamonde ET (2002) Cadmium removal by living cells of the marine microalga
Tetraselmis suecica. Bioresour Technol 84:265-270. doi: 10.1016/S0960-8524(02)00045-7

Rangsayatorn N, Upatham ES, Kruatrachue M, Pokethitiyook P, Lanza GR (2002) Phytoremediation potential of Spirulina (Arthrospira) platensis: biosorption and toxicity studies of cadmium. Environ Pollut 119:45-53. doi:10.1016/S0269-7491(01)00324-4

Rollemberg MC, Gonçalves MLSS, Santos MMC, Botelho MJ (1999) Thermodynamics of uptake of cadmium by Chlorella marina. Bioelectrochem Bioenerg 48:61-68. doi:10.1016/S0302-4598 (98)00220-7

Solisio C, Lodi A, Soletto D, Converti A (2008) Cadmium biosorption on Spirulina platensis biomass. Bioresour Technol 99:5933-5937. doi:10.1016/j.biortech.2007.11.002

Tang YZ, Gin KYH, Aziz MA (2002) Equilibrium model for cadmium adsorption by green algae in a batch reactor. J Environ Eng 128:304-312. doi:10.1061/(ASCE)0733-9372(2002)128:4(304)

Terry PA, Stone W (2002) Biosorption of cadmium and copper contaminated water by Scenedesmus abundans. Chemosphere 47:249-255. doi:10.1016/S0045-6535(01)00303-4

Torres E, Cid A, Herrero C, Abalde J (1998) Removal of cadmium ions by the marine diatom Phaeodactylum tricornutum Bohlin accumulation and long-term kinetics of uptake. Bioresour Technol 63:213-220. doi:10.1016/S0960-8524(97)00143-0

Travieso L, Cañizares O, Borja R, Benítez F, Domínguez AR, Dupeyrón R, Valiente V (1999) Heavy metal removal by microalgae. Bull Environ Contam Toxicol 62:144-151. doi: 10.1007/s001289900853

Tüzün İ, Bayramoğlu G, Yalçin E, Başaran G, Çelik G, Arica MY (2005) Equilibrium and kinetic studies on biosorption of $\mathrm{Hg}(\mathrm{II}), \mathrm{Cd}(\mathrm{II})$ and $\mathrm{Pb}$ (II) ions onto microalgae Chlamydomonas reinhardtii. J Environ Manag 77:85-92. doi:10.1016/j.jenvman.2005.01.028

Yu Q, Kaewsarn P (1999) A model for $\mathrm{pH}$ dependent equilibrium of heavy metal biosorption. Korean J Chem Eng 16:753-757. doi: 10.1007/BF02698347 